\title{
Receptor activities of persistent pollutant serum mixtures and breast cancer risk
}

\author{
Maria Wielsøe', Christian Bjerregaard-Olesen', Peder Kern² and Eva Cecilie Bonefeld-Jørgensen1,3 \\ ${ }^{1}$ Centre for Arctic Health \& Molecular Epidemiology, Department of Public Health, Aarhus University, Aarhus, Denmark \\ 2Department of Gynecology and Obstetrics, Dronning Ingrid's Hospital, Nuuk, Greenland \\ IInstitute for Nursing and Health Science, University of Greenland, Nuuk, Greenland \\ Correspondence should be addressed to E C Bonefeld-Jørgensen: ebj@ph.au.dk
}

\begin{abstract}
Studies on associations between persistent organic pollutants (POPs) and breast cancer risk are inconclusive. The majority of studies have evaluated the effect of single compounds, without considering multiple exposures to and interactions between different POPs. The present study aimed at evaluating breast cancer risk related to combined effects of serum POP mixtures on cellular receptor functions. Data on breast cancer cases $(n=77)$ and controls $(n=84)$ were collected among Greenlandic Inuit women. Serum mixtures of lipophilic POPs (lipPOPs), perfluoroalkyl acids (PFAAs) and dioxin-like POPs were extracted. The effect of the mixture extracts on the estrogen receptor (ER), androgen receptor (AR) and aryl hydrocarbon receptor (AhR) was determined using cell culture reporter gene assays. The serum mixtures were analyzed alone and upon co-exposure with natural receptor ligands to determine agonistic and antagonistic/ competitive activity. We found that the frequency of lipPOP mixtures eliciting no, decreasing, or agonizing xenoandrogenic effect differed by breast cancer status. Using lipPOP mixtures with no effect on AR as reference, the mixtures with decreasing effects reduced breast cancer risk (OR: $0.30(0.12 ; 0.76))$. The AhR-toxic equivalent of serum mixtures was significantly lower in cases than in controls, and a reduced breast cancer risk was found when comparing the third tertile to the first (OR: $0.34(0.14 ; 0.83)$ ). We found no association between the xenoestrogenic activities of lipPOPs or PFAAs and breast cancer risk. Serum lipPOP mixtures are hormone disruptive and may influence breast cancer risk, whereas PFAAs seem to influence breast cancer risk through other pathways.
\end{abstract}

\section{Key Words}

- xenohormone and dioxin-like receptor activity

- arctic

- perfluoroalkyl acid (PFAA)

- polychlorinated biphenyl (PCB)

- organochlorine pesticides (OCPs)

\section{Introduction}

Breast cancer is the most common cancer among women, and tumor growth is often hormone dependent (Ferlay et al. 2015). Estrogen receptors (ER) and progesterone receptor are expressed in up to $75 \%$ of all breast cancer tumors (Anderson et al. 2002, Dai et al. 2016). The androgen receptor (AR) has also been detected and used in breast cancer subtyping. AR-positive tumors comprise
90\% of ER-positive and 55\% of ER-negative tumors (Ogawa et al. 2008, Lakis et al. 2014). Hormones, especially estrogen, play an important role in development and growth of breast cancer (Henderson \& Feigelson 2000, Russo \& Russo 2006, Kotsopoulos \& Narod 2012). Exogenous hormones and endocrine disruptors (EDs) can increase breast cancer risk by mimicking, antagonizing, 
or disrupting the endocrine pathways, often by interacting with hormone receptors and their function, thus altering the homeostatic cellular balance.

Many persistent organic pollutants (POPs) are classified as EDs (Bonefeld-Jorgensen et al. 2014a), including polychlorinated biphenyls (PCBs), organochlorine pesticides (OCPs) and perfluoroalkyl acids (PFAAs). The associations between lipophilic POPs (lipPOP) exposures, such as PCBs and OCPs, and breast cancer risk have been widely studied, but results are inconsistent (Brody et al. 2007, Zhang et al. 2015, Leng et al. 2016). An explanation may be that most epidemiological studies have evaluated the effects on breast cancer risk of single compounds without considering complex mixtures. Additive, antagonistic, or synergistic mixture effects may occur depending on exposure profiles, potency and concentration of the chemicals, thus affecting the overall outcome (Kortenkamp 2007, Evans et al. 2012, Scholze et al. 2014). Moreover, several cell culture studies have shown that ED mixtures can produce synergistic effect; effects not observed when testing compounds individually (Bonefeld-Jorgensen et al. 2001, 2014a, Rajapakse et al. 2002, Kortenkamp 2007, Kjeldsen et al. 2013).

To study the effects of complex human serum mixtures, we have developed methods to assess the receptor activity upon extracting the actual mixture of POPs from human serum and simultaneously remove endogenous sex hormones (Hjelmborg et al. 2006, Kruger et al. 2012, Bjerregaard-Olesen et al. 2015). The aim of the present study was to assess the xenohormone and total dioxin activity in relation to breast cancer risk in Greenlandic Inuit women.

\section{Materials and methods}

\section{Study population}

Greenlandic Inuit women were recruited during 2000-2003 and 2011-2014; see Wielsøe et al. (2017) for a detailed description. Breast cancer diagnosis was confirmed by histology. Approximately $85 \%$ of all breast cancer cases diagnosed during the recruitment period agreed to participate in the study; however, blood samples were only available from $\sim 70 \%$. Controls recruited during 2000-2003 were from two cross-sectional studies on healthy persons (Cote et al. 2006, Deutch et al. 2007). Controls recruited during 2011-2014 were patients with a non-malignant diagnosis at Dronning Ingrids Hospital, Nuuk (Wielsøe et al. 2016). Controls and cases were matched on age and geographical residence. All subjects were of Greenlandic Inuit descent, defined as being born and having more than two grandparents born in Greenland. Blood samples from breast cancer cases were taken when breast cancer was diagnosed and before any treatment was initiated. Information on demographic and lifestyle parameters was collected through assisted questionnaires.

The study was approved by the Greenlandic Ethics Committee (2011-050536) and by The Danish Data Protection Agency (2011-41-6371). All participants gave written informed consent before enrollment in the study.

\section{Measurement of POPs}

Serum POPs and total lipid measurements have been reported in detail previously (Wielsøe etal.2017). PCBs (РCB $99,101,105,118,128,138,153,156,170,180,183,187)$ and OCPs (dichlorodiphenyltrichloroethane (p,p'-DDT), dichlorodiphenyldichloroethylene (p, $\mathrm{p}^{\prime}$-DDE), mirex, $\beta$-hexachlorocyclohexane $(\beta-\mathrm{HCH})$, hexachlorobenzene (HCB), cis- and trans-nonachlor, and oxychlordane) were measured by gas chromatography-mass spectrometry at Le Centre de Toxicologie du Québec, Canada. PFAAs (perfluoroheptanoic acid (PFHpA, C7), perfluorooctanoic acid (PFOA, C8), perfluorononanoic acid (PFNA, C9), perfluorodecanoic acid (PFDA, C10), perfluoroundecanoic acid (PFUnA, C11), perfluorododecanoic acid (PFDoA, C12), perfluorotridecanoic acid (PFTrA, C13), perfluorohexane sulfonate (PFHxS, C6), perfluorooctane sulfonate (PFOS, C8), and perflurooctanesulfonamide (PFOSA, C8)) were measured by liquid chromatography-tandem mass spectrometry at Department of Environmental Science, Aarhus University, Denmark.

\section{Measurement of cotinine and hormone levels}

Current tobacco smoking was assessed by cotinine plasma level using the Calbiotech Cotinine Direct ELISA Kit (Calbiotech Inc., CA, USA) following the manufacturer's instructions. Serum $17 \beta$-estradiol (E2) and $5 \alpha$-dihydrotestostrone (DHT) were determined using the Human Estradiol ELISA kit (Invitrogen) and DHT ELISA (Labor Diagnostika Nord, Nordhorn, Germany) kit, respectively, following manufacturers' instructions. All measurements were carried out using an EL8000 Universal Microplate Reader (BIO-TEK INSTRUMENTS, INC). 


\section{Serum extraction of POPs}

In each extraction batch, a procedural blank consisting of double distilled water and a serum control sample were included and analyzed in parallel. The control serum was obtained from female blood donors at Aarhus University Hospital, Denmark.

The lipPOP mixture and the PFAA mixture were extracted in the same run from a $3 \mathrm{~mL}$ serum sample, while simultaneously removing endogenous hormones. For a detailed laboratory procedure see Hjelmborg et al. (2006) and Bjerregaard-Olesen et al. (2015). Briefly, the serum samples were subjected to solid phase extraction (SPE, OASIS HLB, Waters) and liquid-liquid extraction (Hexane:EtOAc 9:1). The supernatant containing lipPOPs was fractionated by high-performance liquid chromatography (HPLC) (Hjelmborg et al. 2006), while the aqueous phase, containing PFAAs, was further extracted with liquid-liquid extraction (tetrahydrofuran:hexane 3:2), HPLC fractionation and finally a weak anion exchange (WAX; OASIS WAX, Waters) (Bjerregaard-Olesen et al. 2015). The serum mixtures containing lipPOPs (fraction F1) and PFAAs (fraction F3-W2) were evaporated at $30^{\circ} \mathrm{C}$ under $\mathrm{N} 2$ until nearly dryness and stored at $-80^{\circ} \mathrm{C}$ until analysis. Samples collected 2000-2003 and 2011-2014 were subjected to lipPOP extraction and tested for xenoestrogenic and xenoadrogenic activities. Only samples collected between 2011 and 2014 were subjected to PFAA extraction and tested for xenoestrogenic activities.

Dioxin and dioxin-like POPs were extracted from serum samples collected between 2011 and 2014, as dioxinlike activity for the period 2000-2003 has been estimated and reported previously using a slightly different method (Bonefeld-Jorgensen et al. 2011). For the extraction method, see Morck et al. (2014). After conditioning of a Discovery C18 SPE column with n-hexane, ethyl acetate, methanol and double distilled water, the $2 \mathrm{~mL}$ serum was added. After column drying, the samples were eluted with n-hexane and then further extracted using a Supelco column and a column with pre-activated Florisil. The columns were conditioned before the eluate from the SPE extraction was added. The dioxins and dioxin-like compounds were eluted from the columns with (1) n-hexane and the Florisil column was further eluted with (2) n-hexane:dichloromethane (98:2) and (3) dichloromethane. The final combined extract from the three elutions was evaporated using a rotary evaporator and further evaporated to near dryness using N2. The samples were stored at room-temperature until the aryl hydrocarbon receptor (AhR) activity analyses was conducted.

\section{Determination of xenoestrogenic activity}

The estrogenic and antiestrogenic activities of the extracted lipPOP mixture (fraction F1) and PFAA mixture (fraction F3-W2) were assessed using stable transfected MVLN cells (provided by M Pons, INSERM, Montpellier, France). Experiments were carried out at cell passage 2-10. See Bonefeld-Jorgensen et al. (2005) for detailed information on the ER assay. In short, MVLN cells were seeded in white 96-well microtiter plates (Perkin Elmer) with a density of approximately $8.5 \times 10^{4}$ cells/well. The serum mixtures were tested alone (XER) and for competitive measurements (XERcomp) upon co-exposure with 24pM E2 (SigmaAldrich). The dry serum mixtures were reconstituted as previously described on the day of analysis (BonefeldJorgensen et al. 2006). The cells were harvested after exposure to the serum mixtures for $20 \mathrm{~h}$, and luciferase activity and protein content were measured. An E2 concentrationresponse control (1.5-300 pM) was performed in parallel in each assay.

\section{Determination of xenoandrogenic activity}

The androgenic and antiandrogenic activities of the extracted lipPOP mixture (fraction F1) were assessed using the Chinese hamster ovary cell line CHO-K1 (ATCC no. CCL-61). The CHO-K1 cells were transiently co-transfected with a MMTV-LUC reporter vector (provided by R M Evans, Howard Hughes Medical Institute, CA, USA) and an AR expression plasmid pSVARO (provided by A O Brinkmann, Erasmus University, Rotterdam, The Netherlands). Experiments were carried out at cell passage 2-10. For seeding and transfection of the CHO-K1 cell for the AR assay, see Kjeldsen et al. (2013). The serum mixtures were tested alone (XAR) and upon co-exposure (XARcomp) with $25 \mathrm{pM}$ methyltrienolone (R1881, Perkin Elmer) or $12 \mathrm{pM}$ dihydrotestosterone (DHT, Sigma-Aldrich). The synthetic AR agonist R1881 was used for co-treatment analyses for the samples collected during 2000-2003 and as positive controls; DHT was used in the analyses of samples collected during 2011-2014 as US export of R1881 was prohibited. Our tests have shown similar and comparable data using the two AR ligands (Kjeldsen et al. 2013). The dry serum mixtures were reconstituted similarly to the mixtures for xenoestrogenic activity measurement in Dulbecco's Modified Eagle's Medium: Nutrient Mixture F-12 with phenol red (DMEM/F-12, no glutamine, Gibco) with supplements (4 mM L-glutamine (Sigma-Aldrich), $128 \mathrm{mg} / \mathrm{L}$ hexamycin (Sandoz, Denmark)) and $20 \%$ charcoal dextran-stripped fetal bovine serum 
(CD-FBS, HyClone VWR, Denmark). After reconstitution, $100 \mu \mathrm{L} /$ well of constituted serum mixture with or without co-exposure was added to the 96-well plate in triplicate without removing the transfection medium. Thus, the final exposure was DMEM/F-12 medium with supplements ( $2 \mathrm{mM}$ L-glutamine, $64 \mathrm{mg} / \mathrm{L}$ hexamycin) and 10\% CD-FBS and for the competitive design $25 \mathrm{pM}$ R1881/12 pM DHT.

An R1881/DHT concentration-response control (1-250 pM/2-200 pM, respectively) was performed in parallel in each assay, and as an inhibitor control a hydroxyflutamide (MicroMol GmbH, Luckenwalde, Germany) concentrationresponse control $(0.5-500 \mathrm{nM})$ was included in each assay. After exposure for $20 \mathrm{~h}$, cells were harvested, and luciferase activity and protein content was measured.

\section{Determination of total dioxin-like activity}

For the AhR assay, Hepa $1.12 \mathrm{cR}$ cells stably transfected with a dioxin-responsive element luciferase reporter vector (pGudLuc1.1) were used. Experiments were carried out at cell passage $2-10$. The day before assay, the dry serum mixtures were dissolved in $10 \mu \mathrm{L}$ DMSO: $\mathrm{H}_{2} \mathrm{O}$ (1:1). The dissolved serum mixtures were diluted in $500 \mu \mathrm{L}$ pure $\alpha$-minimal essential medium with Glutamax ( $\alpha$-MEM, GibcoBRL, UK). For further dilution, $150 \mu \mathrm{L}$ of the samples were transferred to a new tube containing $250 \mu \mathrm{L} \alpha$-MEM with $10 \%$ fetal calf serum and $0.064 \mathrm{mg} / \mathrm{mL}$ hexamycin. The cells were exposed for $4 \mathrm{~h}$ to $100 \mu \mathrm{L}$ dissolved serum mixture extract per well. After exposure for $4 \mathrm{~h}$, cells were harvested, and luciferase activity and protein content were measured. For the detailed procedure, see Long et al. (2006) and Morck et al. (2014).

\section{Statistics}

Statistical analyses were performed using IBM SPSS Statistics 24, Microsoft Excel, and SigmaPlot 11.0. The statistical significance level was $P \leq 0.05$ and borderline significance was $P \leq 0.08$.

\section{Calculation of the xenoestrogenic and xenoandrogenic activities}

The xenoestrogenic and xenoandrogenic activities of the samples are expressed as percentage induction of the solvent control (\% of SC). The mean luciferase activity (RLU/count protein) of the solvent control was set to $100 \%$ and the relative xenohormone activity is given as the ratio between samples above solvent control. The activity of each sample was the mean of a triplicate measurement in one assay. The coefficient of variation (CV) within the triplicate measurements was below $10 \%$ for most samples.
The samples were categorized corresponding to their effect (Fig. 1). For the xenoestrogenic analyses, samples were categorized as decreasing samples ( $\left.\mathrm{XER} \leq \mathrm{SC}-\mathrm{CV}_{\text {serum control }}\right)$, agonizing samples (XER $\left.\geq \mathrm{SC}+\mathrm{CV}_{\text {serum control }}\right)$ and samples within $\mathrm{CV}$ (XER within $\mathrm{SC} \pm \mathrm{CV}_{\text {serum control), where }}$ $\mathrm{CV}_{\text {serum control }}$ is the inter-assay $\mathrm{CV}$ for the serum control, which was extracted and analyzed in parallel with the samples in each assay. For the XERcomp analyses, the samples were categorized as antagonizing samples (XERcomp $\leq \mathrm{SC}-\mathrm{CV}_{\text {serum control }}$ ), enhancing samples (XERcomp $\left.\geq \mathrm{SC}+\mathrm{CV}_{\text {serum control }}\right)$ and samples within $\mathrm{CV}$ (XERcomp within $\mathrm{SC} \pm \mathrm{CV}_{\text {serum control }}$ ). A calculation example for XER(lipPOP) with the inter-assay $\mathrm{CV}_{\text {serum control }}$ of $8.1 \%$ is given: $\mathrm{XER}(\mathrm{lipPOP})$ below $91.9 \%(=100 \%-8.1 \%)$ were decreasing, XER(lipPOP) above $108.1 \%(=100 \%+8.1 \%)$ were agonistic, and XER(lipPOP) within the range 91.8-108.1\% were categorized as samples with no effect (within CV) (Fig. 1A, B and C). For AR analyses, the samples were categorized in a similar way.

The xenoestrogenic activity of the lipPOP and PFAArelated estradiol equivalents (EEQ) were calculated for each sample based on the measurement without co-exposure with E2. Using SigmaPlot 11.0 (SYSTAT software), the E2 titration was fitted into a four-parameter sigmoidal Hill curve and the POP-related EEQs for each sample was calculated by interpolation of their corresponding activity values onto the dose-response curve. Samples with an XER activity below the lower plateau of the sigmoidal curves were given a value of the lowest measured EEQ/2 (Fig. 1D).

\section{Calculation of the dioxin-like AhR activities}

The dioxin-like AhR activity of the serum extracts was expressed as a percentage of the SC. The AhR-mediated 2,3,7,8-tetrachlorodibenzodioxin (TCDD) equivalent (AhR-TEQ) values for each sample were calculated as described (Long et al. 2006, Morck et al. 2014). The TCDD titration was fitted into a four-parameter sigmoidal Hill curve using SigmaPlot, and the AhR-TEQ of the samples was calculated. The final AhR-TEQ of serum samples was obtained by subtracting the AhR-TEQ of a procedural extraction blank. The AhR-TEQ is given both without and with serum lipid correction. Samples with AhR-TEQ below procedural extraction blank were given the value corresponding to the lowest detected AhR-TEQ/2. For the categorical analyses, AhR-TEQ was divided into tertiles based on the distribution of controls.

\section{Correlations}

Pearson correlations were used to assess the relationship between xenohormone activities and serum PFAA levels, 
A Extracts tested alone

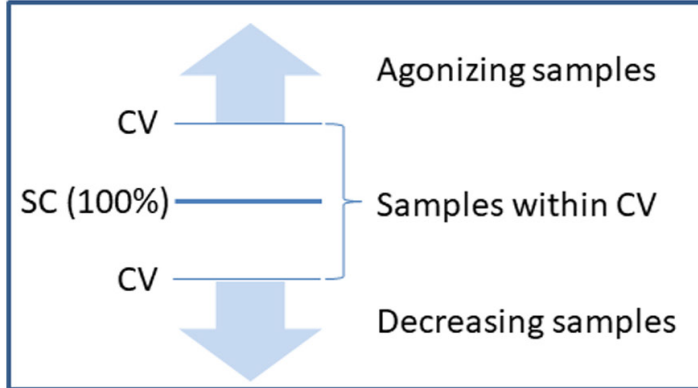

B Extracts tested with co-exposure

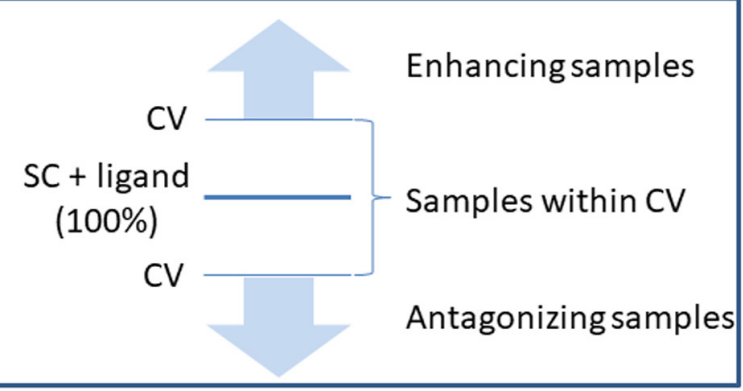

C

XER(lipPOP) samples

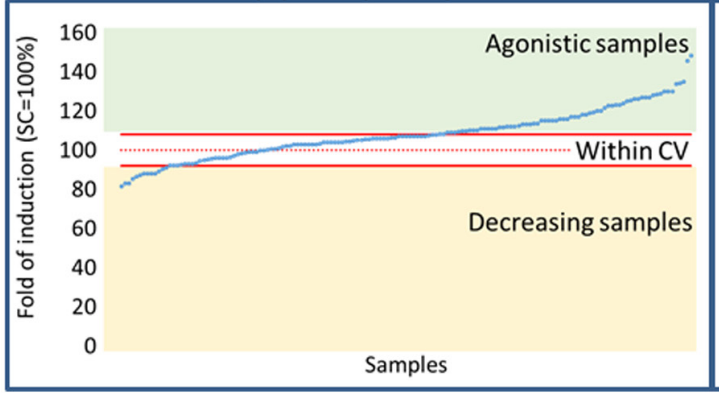

$\mathrm{D}$ Calculation of EEQ

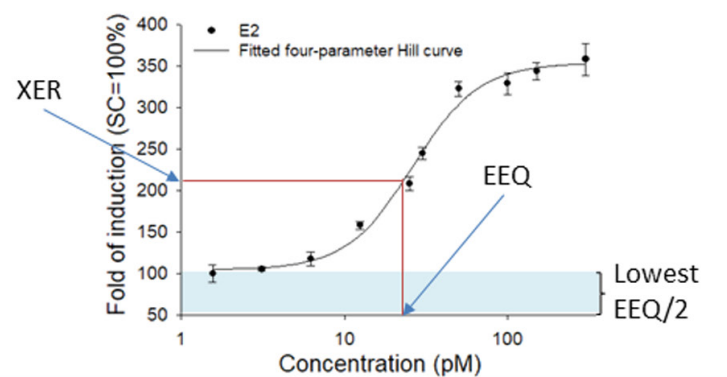

Figure 1

Categorization of samples by effects on estrogen and androgen receptors. The samples were categorized corresponding to their effect. (A) Categorization of samples tested alone; (B) categorization of samples tested with co-exposure, 24 pM E2 in estrogen receptor assays and 25 pM $\mathrm{R} 1881 / 12 \mathrm{pM}$ DHT in androgen receptor assays; (C) fold induction per XER(lipPOP) sample with solvent control=100\% (dashed red line) \pm inter-assay CV (solid red line); (D) calculation of EEQ from the E2 dose-response curve; SC, solvent control; CV, coefficient of variation; Ligand, E2 in the ER assay and R1881/DHT in the AR assay; EEQ, estradiol (E2) equivalents. A full color version of this figure is available at http://dx.doi.org/10.1530/ERC-17-0366.

and Pearson's partial correlations were used to assess the relationship between xenohormone activities and serum lipPOP levels with adjustment for total serum lipid. Multiple statistical tests were carried out but without statistical adjustment of the significance level as we expect a high degree of correlation between some of the tests.

\section{Comparison of cases and control}

The independent Student's $t$-test was used to test the differences in numeric variables between cases and controls. The distribution of the variables was checked by Q-Q plots and when non-normal distribution was found, data were $\ln$-transformed to improve normality. $\chi^{2}$ test was used to test for distribution differences in categorical variables between cases and controls. When the $\chi^{2}$ test was significant, post hoc z-test comparing column proportions with Bonferroni adjusted $P$ values were conducted.

\section{Odds ratio estimates}

To estimate odds ratios (ORs), unconditional logistic regression models were used, and the estimates were obtained controlling for potential confounders. For the receptor activity analyses, the potential confounders included age (continuous), parity (continuous), plasma cotinine level (continuous), BMI (three categories), breastfeeding (yes/no) and total serum lipid (in quintiles, only in lipPOP analyses). Confounding by the variables of interest was assessed using the change in estimate approach through backward elimination. The change in estimate between the full logistic model and the model without the variable of interest was calculated. If the change in OR estimate was above $10 \%$, the variable was considered to be a confounder and included in the final model.

Subgroup analyses of the associations between the activities and breast cancer risk were performed for categories of age ( $\leq 50$ vs $>50)$, BMI ( $<25$ vs $\geq 25$ ), smoking (never vs ever), menopausal status (premenopausal vs postmenopausal), parity ( $\leq 2$ vs $\geq 3$ ) and recruitment period (2000-2003 vs 2010-2014).

\section{Results}

The study population included 77 breast cancer cases (approximately $70 \%$ of all cases in the period) and 84 controls. The characteristics and serum POP levels of the study population are shown in Tables 1 and 2, 
Table 1 Demographic and reproductive characteristic for breast cancer cases and controls.

\begin{tabular}{|c|c|c|c|c|c|c|c|}
\hline \multirow[b]{2}{*}{ Parameters } & \multicolumn{3}{|c|}{ Cases } & \multicolumn{3}{|c|}{ Controls } & \multirow[b]{2}{*}{ P-Value } \\
\hline & $N(n)$ & Median & IQR & $N(n)$ & Median & IQR & \\
\hline \multicolumn{8}{|l|}{ Demographic factors } \\
\hline Age (years) & $77(77)$ & 52.0 & 18.0 & $84(84)$ & 50.0 & 18.0 & $0.039 a$ \\
\hline$\leq 50$ & $34(44.2 \%)$ & & & $50(59.5 \%)$ & & & \\
\hline $51-55$ & $11(14.3 \%)$ & & & $6(7.1 \%)$ & & & \\
\hline $56-59$ & $7(9.1 \%)$ & & & $8(9.5 \%)$ & & & $0.183^{b}$ \\
\hline$\geq 60$ & $25(32.5 \%)$ & & & $20(23.8 \%)$ & & & \\
\hline BMI $\left(\mathrm{kg} / \mathrm{m}^{2}\right)$ & $77(48)$ & 26.3 & 6.3 & $84(75)$ & 27.7 & 6.1 & $0.041^{a}$ \\
\hline$<25$ & $18(37.5 \%)$ & & & $23(37.5 \%)$ & & & \\
\hline $25-30$ & $24(50.0 \%)$ & & & $31(41.3 \%)$ & & & $0.128^{\mathrm{b}}$ \\
\hline$>30$ & $6(12.5 \%)$ & & & $21(28.8 \%)$ & & & \\
\hline Smoking status & $77(70)$ & & & $84(80)$ & & & \\
\hline Never & $6(8.6 \%)$ & & & $16(20.0 \%)$ & & & \\
\hline Former & $18(25.7 \%)$ & & & $20(25.0 \%)$ & & & $0.132^{b}$ \\
\hline Current & $46(65.7 \%)$ & & & $44(55.0 \%)$ & & & \\
\hline Plasma cotinine (ng/mL) & $77(74)$ & 46.3 & 239.7 & $84(76)$ & 40.5 & 212.9 & $0.209^{a}$ \\
\hline Total serum lipid (g/L) & $77(76)$ & 6.4 & 2.6 & $84(84)$ & 6.8 & 1.5 & $0.024^{a}$ \\
\hline \multicolumn{8}{|l|}{ Reproductive factors } \\
\hline Menopausal status & $77(66)$ & & & $84(75)$ & & & \\
\hline Premenopausal & $24(36.4 \%)$ & & & $24(32.0 \%)$ & & & $0.585^{b}$ \\
\hline Postmenopausal & $42(63.6 \%)$ & & & $51(68.0 \%)$ & & & \\
\hline Full term pregnancies & $77(60)$ & 3.0 & 2.8 & $84(67)$ & 3.0 & 4.0 & $0.799^{a}$ \\
\hline Breastfed & $77(52)$ & & & $84(68)$ & & & \\
\hline Ever breastfed (yes) & $46(88.5 \%)$ & & & $59(86.8 \%)$ & & & $0.781^{b}$ \\
\hline \multicolumn{8}{|l|}{ Serum hormone levels } \\
\hline Estradiol (pM) & $77(67)$ & 95.9 & 181.5 & $84(65)$ & 99.0 & 144.5 & $0.860^{a}$ \\
\hline Premenopausal & $29(21)$ & 246.0 & 313.4 & $33(23)$ & 189.0 & 204.5 & $0.156^{a}$ \\
\hline Postmenopausal & $47(38)$ & 81.1 & 110.8 & $51(42)$ & 93.5 & 85.4 & $0.396^{a}$ \\
\hline Dihydrotestosterone (pM)* & $46(45)$ & 738.9 & 360.6 & $53(53)$ & 775.0 & 380.9 & $0.616^{a}$ \\
\hline
\end{tabular}

Significant and borderline significant $P$-values are given in bold

alndependent samples $t$-test on In-transformed variables; bPearson's chi²-test; *only measured in the 2010-2014 recruitment period.

BMI, body mass index; IQR, interquartile range; $N$, total number of subjects; $n$, number of subject with information on the corresponding variable;

$P$-value, testing the difference between cases and controls.

Table 2 Serum POP levels in breast cancer cases and controls.

\begin{tabular}{|c|c|c|c|c|c|c|c|}
\hline \multirow[b]{2}{*}{ Parameters } & \multicolumn{3}{|c|}{ Cases } & \multicolumn{3}{|c|}{ Controls } & \multirow[b]{2}{*}{ P-Value } \\
\hline & $N(n)$ & Median & IQR & $N(n)$ & Median & IQR & \\
\hline$\sum \mathrm{PCB}(\mathrm{ng} / \mathrm{mL})$ & 77 (76) & 9.4 & 16.9 & $84(84)$ & 7.9 & 13.7 & 0.046 \\
\hline $\bar{\sum}$ estrogenic-PCB (ng/mL) & $77(76)$ & 1.0 & 1.5 & $84(84)$ & 0.9 & 1.2 & 0.087 \\
\hline $\bar{\sum}$ antiestrogenic-PCB (ng/mL) & $77(76)$ & 2.9 & 5.0 & $84(84)$ & 2.6 & 4.9 & 0.083 \\
\hline $\bar{\Sigma}$ CYPinducing-PCB (ng/mL) & $77(76)$ & 5.6 & 10.3 & $84(84)$ & 4.7 & 8.2 & 0.034 \\
\hline$\sum$ dioxinlike-PCB (ng/mL) & $77(76)$ & 0.8 & 1.3 & $84(84)$ & 0.7 & 1.2 & 0.153 \\
\hline$\sum O C P(n g / m L)$ & $77(75)$ & 12.8 & 20.5 & $84(84)$ & 10.5 & 15.0 & 0.026 \\
\hline$\sum$ PFCA $(\mathrm{ng} / \mathrm{mL})$ & $77(77)$ & 8.6 & 12.1 & $84(81)$ & 7.0 & 13.6 & 0.225 \\
\hline$\sum$ PFSA (ng/mL) & 77 (77) & 38.1 & 53.3 & $84(81)$ & 19.9 & 34.3 & 0.014 \\
\hline$\sum$ PFAA (ng/mL) & 77 (77) & 48.9 & 73.9 & $84(81)$ & 27.9 & 49.1 & 0.020 \\
\hline
\end{tabular}

Significant and borderline significant $P$-values are given in bold; $\sum$ PCB: РCB 99, 101, 105, 118, 128, 138, 153, 156, 170, 180, 183, 187; $\sum$ estrogenicPCB: PCB 101, 187; $\sum$ antiestrogenicPCB: РCB 105, 118, 128, 138, 156, 170; $\sum$ CYPinducingPCB: PCB 99, 153, 180, 183; $\sum$ dioxinlikePCB: PCB 105, 118, 156; $\sum$ OCP: $p, p^{\prime}-D D T, p, p^{\prime}-D D E$, mirex, $\beta-H C H, H C B$, cis- and trans-nonachlor, and oxychlordane; $\sum$ PFCA: PFHpA, PFOA, PFNA, PFDA, PFUnA, PFDoA and PFTrA; $\sum$ PFSA: PFHxS, PFOS and PFOSA; $\sum$ PFAA: $\sum$ PFCA $+\sum$ PFSA.

$N$, total number of subjects; $n$, number of subject with information on the corresponding variable; IQR, interquartile range; $P$-value, testing the difference between cases and controls with independent samples $t$-test on In-transformed variables. 


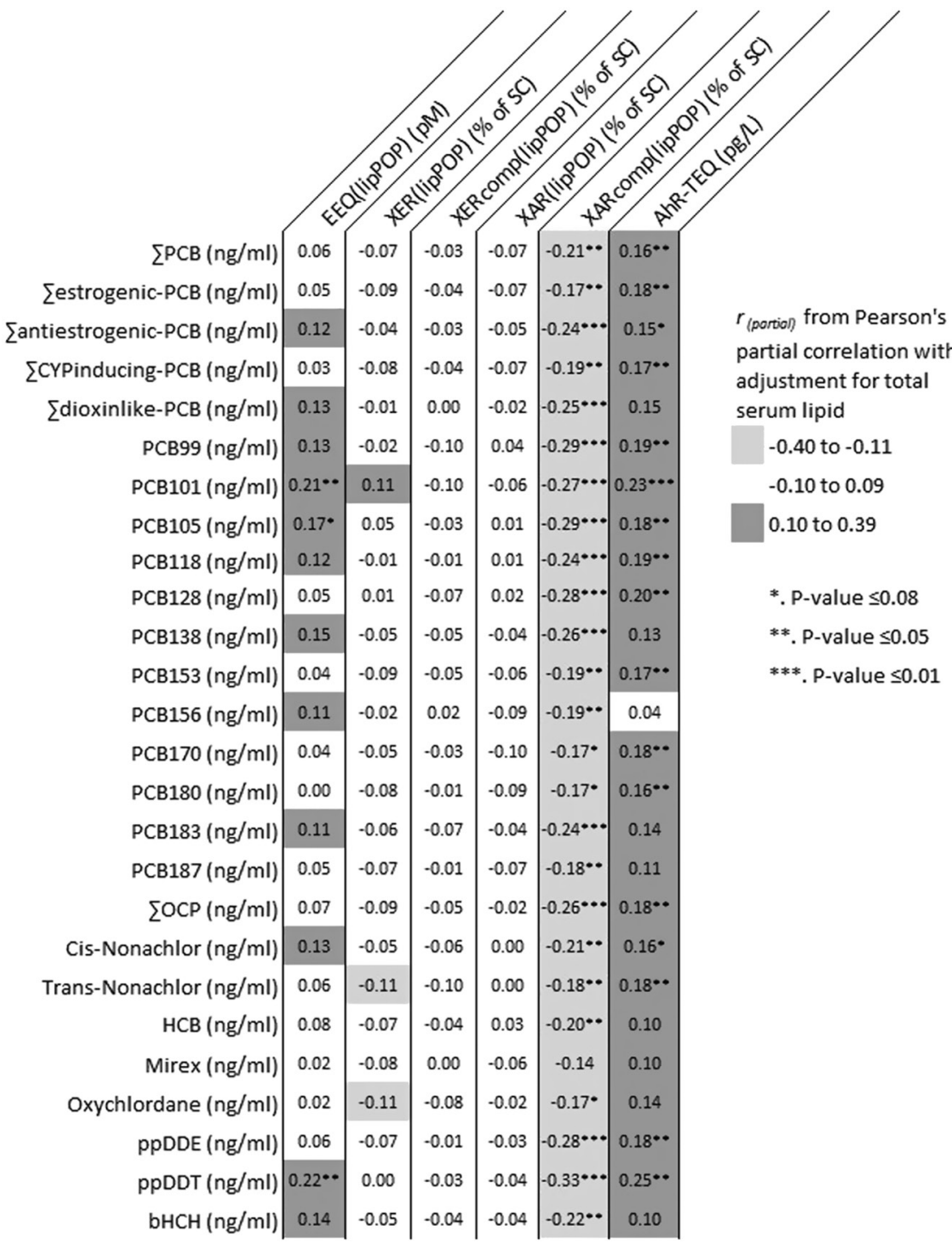

\section{Figure 2}

Correlation between lipPOP-induced receptor activity and serum lipPOP levels. Pearson's partial correlation. The correlations between lipPOPinduced receptor activity and serum lipPOP levels were assessed under adjustment for total serum lipid. Light gray indicated weak negative correlations and dark gray indicates weak positive associations. The correlation coefficients is given in each cell. $\sum$ PCB: PCB 99, 101, 105, 118, 128 , 138, 153, 156, 170, 180, 183, 187; $\sum$ estrogenicPCB: PCB 101, 187; $\sum$ antiestrogenicPCB: РCB 105, 118, $128,138,156,170 ; \sum$ CYPinducingPCB: PCB 99, $153,180,183 ; \sum$ dioxin-likePCB: РCB 105, 118, 156; $\sum O C P: p, p^{\prime}-D D T, p, p^{\prime}-D D E$, mirex, $\beta-H C H, H C B$, cis- and trans-nonachlor, and oxychlordane. respectively. The age distribution was similar between cases and controls, although cases were slightly older. BMI was slightly lower for cases compared to controls, but the distribution between normal weight, overweight and obese was not significantly different. None of the other characteristic in Table 1 differed significantly between cases and controls. Higher serum POP concentrations were found in cases compared to controls both for PCBs, OCP, and PFAAs (Table 2).

\section{Correlations between receptor activities and serum POP levels}

Correlations between lipPOP-induced receptor activities and serum concentrations of the compounds are shown in Fig. 2. The correlations were generally weak, with the strongest correlation having a correlation coefficient of -0.33 . We generally found positive correlations between $\mathrm{EEQ}$ (lipPOP) and PCBs, but the statistical significance were low with only $8 \%$ of the correlations being significant. In contrast, XARcomp correlated negatively and significantly with all (but one) lipPOPs. The correlations were weak to moderate, and $85 \%$ being significant. Correlations between AhR-TEQ and serum lipPOP levels were all positive and $58 \%$ of the correlations were significant.

Figure 3 shows the correlations between PFAA xenoestrogenic activities and PFAA serum levels. XERcomp(PFAA) was negatively correlated with PFAA serum levels, and statistically significant for $36 \%$ of the correlations (PFDA, PFUnA, PFDoA $\sum$ PFCA).
(2) 2018 Society for Endocrinology Published by Bioscientifica Ltd. Printed in Great Britain 


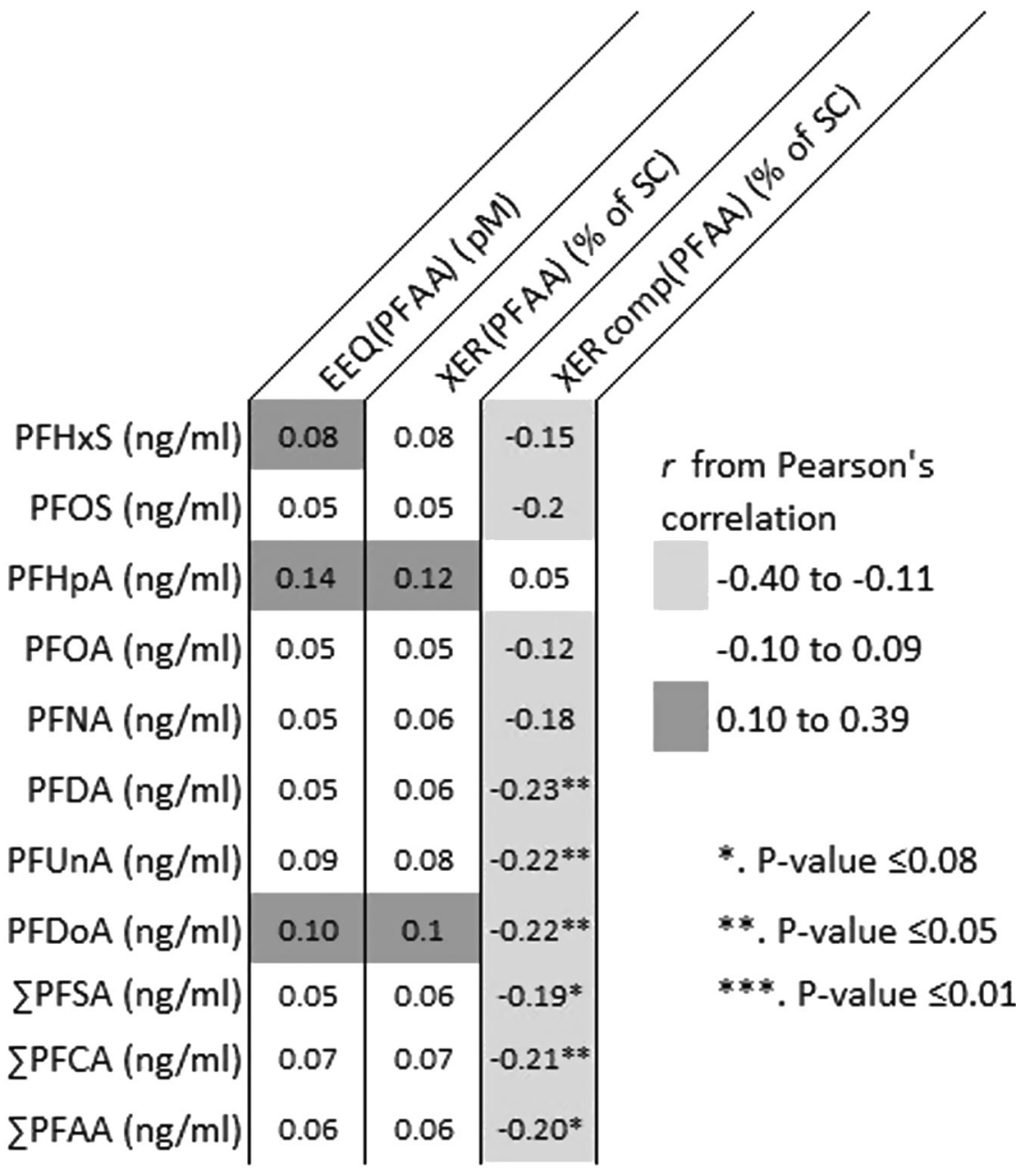

\section{Figure 3}

Correlation between PFAA-induced xenoestrogenic activity and serum PFAA levels. Pearson's correlation. Light gray indicated weak negative correlations and dark gray indicates weak positive associations. The correlation coefficients is given in each cell. $\sum$ PFCA: PFHpA, PFOA, PFNA, PFDA, PFUnA, PFDoA and PFTrA; $\sum$ PFSA: PFHXS, PFOS and PFOSA; $\sum$ PFAA: $\sum \mathrm{PFCA}+\sum \mathrm{PFSA}$

\section{Comparison of receptor activities in breast cancer cases and controls}

Receptor activity comparisons between breast cancer cases and controls were analyzed as continuous (Table 3) and categorized variables (Fig. 4). For continuous variables, AhR-TEQ (with and without lipid standardization) differed between the groups, being significantly lower in cases than that in controls (Table 3 ).

The samples were categorized according to their effect on the receptors. For XAR(lipPOP), the frequency of samples eliciting no, decreasing, or agonizing activity differed by breast cancer status (Fig. 4). Post hoc tests revealed that the frequency of samples with no effect (within CV) were higher in cases $(51.4 \%)$ than in controls $(31.3 \%)$, the frequency of samples with decreasing effects was lower in cases $(26.5 \%)$ than controls (49.3\%) and the frequency of samples with agonistic activities was similar in the two groups (cases: $22.1 \%$ and controls $19.4 \%$, Fig. 4). None of the other categorized variables (estrogenic activities for lipPOP and PFAA mixtures) differed by breast cancer status (Fig. 4). http://erc.endocrinology-journals.org https://doi.org/10.1530/ERC-17-0366
C) 2018 Society for Endocrinology Published by Bioscientifica Ltd. Printed in Great Britain

\section{Associations between receptor activities and breast cancer risk}

The associations between receptor activities and breast cancer risk were analyzed for continuous and categorical exposure variables (Table 4 and Fig. 5 ). In the analyses of continues variables, none of the exposure variables altered breast cancer risk significantly (Table 4). When stratifying for the categorical effects of samples in the continuous analyses, the XER(lipPOP) was negatively related to breast cancer risk (OR: 0.92, 95\% CI: 0.85; 0.99) in samples with agonistic effect. For the adjusted analyses, EEQ(lipPOP) reduced the risk borderline significantly (OR: 0.89, 95\% CI: 0.79; 1.00) (Table 4).

Figure 5 shows the results for the analyses with categorical exposure variables. The OR for breast cancer risk was significantly reduced for the samples in the category with decreasing XAR(lipPOP) activity compared to the samples with no effect (within CV) (OR: 0.30, 95\% CI: 0.12; 0.76) (Fig. 5A). For the categorized analyses of the dioxin-like activity, significant associations were found 
(Fig. 5B). For the non-lipid standardized variables, reduced risk was seen for the second (OR: 0.42, 95\% CI: 0.20; 0.87) and third tertile (OR: $0.36,95 \%$ CI: 0.13; 0.84), using the first tertile as reference (Fig. 5B). Similar results were found for the lipid standardized variable; however, the results were only significant for the third tertile (Fig. 5B).

We found no significant relation between EEQ(PFAA), XER(PFAA) or XERcomp(PFAA) and breast cancer (Fig. 5C and Table 4), neither for continuous nor categorical variables.

\section{Subgroup analyses}

In the subgroup analyses, we evaluated the associations between breast cancer risk, xenohormone and dioxinlike activity according to age, BMI, smoking history, menopausal status, parity and recruitment period (data not shown). The association estimates were homogeneous across all subgroups.

\section{Discussion}

Overall, only few of the measured POP-induced receptor activities were associated with breast cancer risk. Breast cancer cases had lower lipPOP-related AhR-TEQ levels (Table 3), and we found a significantly reduced breast cancer risk with high AhR-TEQ levels (Fig. 5B). For xenoandrogen activities, cases had a lower frequency of decreasing XAR(lipPOP) activity (Fig. 4), and the risk was significantly reduced for the category with decreasing XAR(lipPOP) compared to a reference sample group with no XAR(lipPOP) activity (Fig. 5A). None of the POP-induced xenoestrogenic activities was associated with breast cancer risk (Table 4). Several receptor activities correlated significantly, but very weakly, with serum concentrations of individual POPs (Figs 2 and 3).

Lifelong exposure to estrogens is a known risk factor for breast cancer. LipPOPs are potential EDs, and xenoestrogenic and xenoantiestrogenic activity of single compounds and serum mixtures have been reported (Bonefeld-Jorgensen et al. 2001, 2006). We have previously reported weak positive associations between serum concentrations of individual lipPOPs and breast cancer in this study population (Wielsøe et al. 2017) and hypothesized that the effect of lipPOPs might be through their endocrinedisrupting potential. However, the present study could not confirm the hypothesis clearly with respect to POPs' impact on the ER function (Table 4). The correlations between EEQ(lipPOP)/XER(lipPOP)/XERcomp(lipPOP) and the serum concentrations of the lipPOPs were very weak and mostly non-significant (Fig. 2). The mixture 

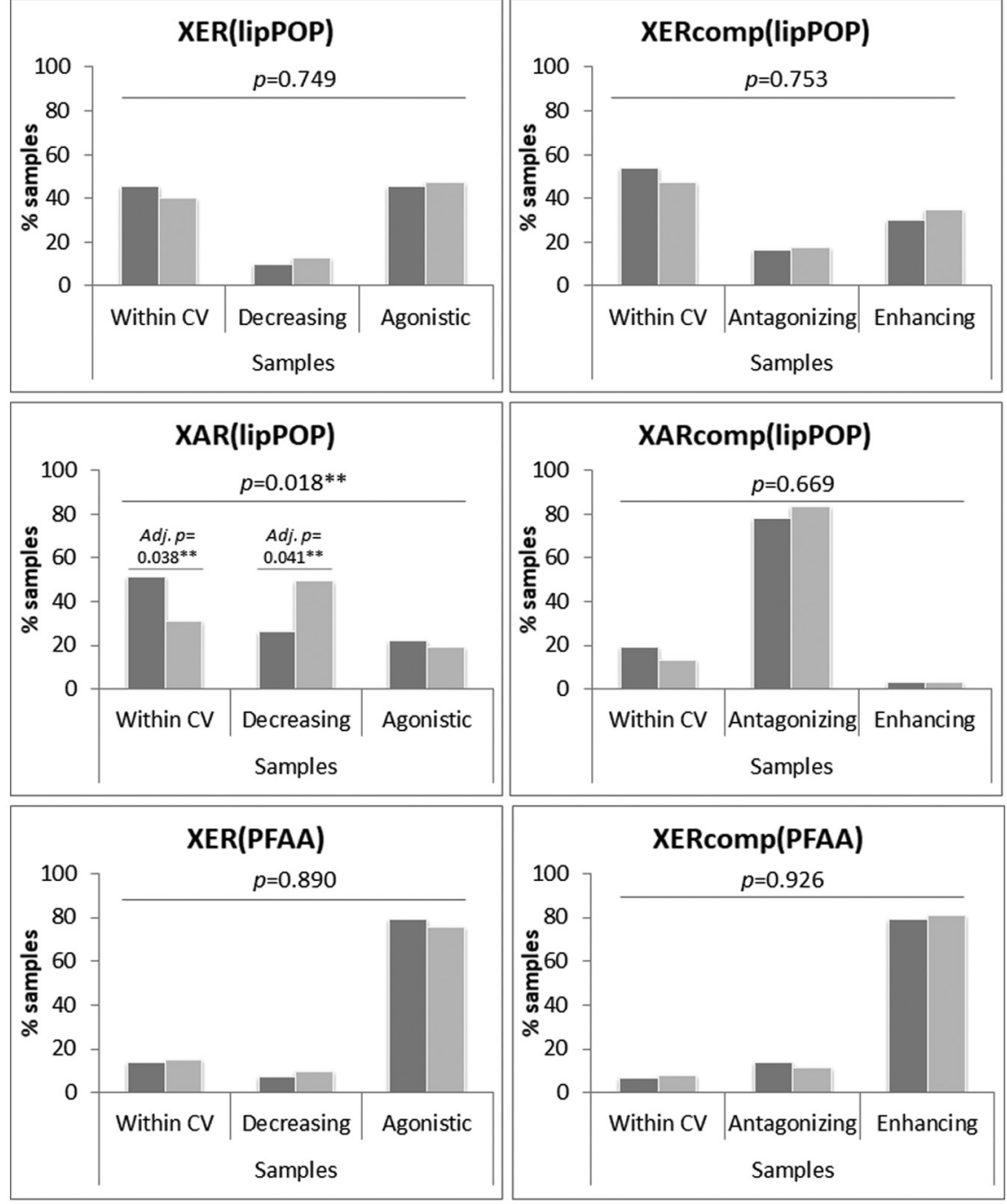

Cases Controls

effects of the extracted serum lipPOPs are complex to interpret since some POPs display estrogenic activity and can have an additive or synergistic effect, whereas others are anti-estrogenic and might counteract the effect of the estrogenic compounds. The weak correlations between xenoestrogenic activity and lipPOP serum concentrations (Fig. 3) and the lack of associations between the lipPOP-related xenoestrogen activity and breast cancer might be explained by the complexity of the serum mixture. Two published Spanish studies, using a approach similar to ours, investigated the xenoestrogenic activity of bioaccumulated lipophilic xenoestrogens from adipose tissue and serum samples in relation to breast cancer (Ibarluzea et al. 2004, Pastor-Barriuso et al. 2016). Both studies found, in contrary to our present results, a strong positive association between xenoestrogenic activity and breast cancer risk. Although the approach is similar, there are important differences in the methods for extraction and

\section{Figure 4}

Distribution of POP-induced categorical xenohormone activities by breast cancer cases and controls. Chi-square tests was used to compare the distribution between cases and controls. XER and XAR: receptor activity of the serum extracts tested alone; XERcomp and XARcomp: competitive receptor activity of the serum extracts tested with co-treatment by potent receptor ligand; $P$ : $P$-value from overall test; adj. $P$ : adjusted $P$-value from post hoc test; $* *$ indicates significant differences $(P$-values $<0.05)$ from the tests; for definition of decreasing/ agonizing and antagonizing/enhancing samples, see 'Methods' section. for determining xenoestrogenic activity; most importantly, lipPOPs' effect on cell proliferation and not ER activity was determined in the two Spanish studies. Differences in study population characteristics, extraction method, determination of xenoestrogenic activity and exposure profiles are the most likely reasons for the incongruence of results of the Spanish studies and the present study.

Although the most accepted risk factor for breast cancer is the accumulative dose of estrogen throughout life, other hormones, such as androgens, can affect breast cancer risk. A meta-analysis of nine prospective studies found that postmenopausal breast cancer risk increases with increasing levels of several sex hormones, including androgens (Key et al. 2002). Others have suggested a protecting effect of androgens, as androgens may inhibit breast development (Dimitrakakis \& Bondy 2009). The mechanism underlying the effect of androgens is currently debated, but the importance of the estrogen/androgen 
Table 4 Associations between breast cancer and receptor activity of serum extracts.

\begin{tabular}{|c|c|c|c|c|}
\hline & \multicolumn{3}{|c|}{ Unadjusted analysis } & \multirow{2}{*}{$n$ (cases/controls) } \\
\hline & $n$ (cases/controls) & OR $(95 \% \mathrm{Cl})$ & $P$ & \\
\hline \multicolumn{5}{|l|}{ XER activity of lipPOP } \\
\hline EEQ(lipPOP) (pM) & 73/71 & $0.95(0.86 ; 1.04)$ & 0.281 & $56 / 63$ \\
\hline XER(lipPOP) (\% of SC) & $73 / 80$ & $0.99(0.96 ; 1.01)$ & 0.263 & $56 / 63$ \\
\hline XERcomp(lipPOP) (\% of SC) & $73 / 80$ & $1.00(0.98 ; 1.03)$ & 0.957 & $56 / 63$ \\
\hline \multicolumn{5}{|l|}{ XAR activity of lipPOP } \\
\hline XAR(lipPOP) (\% of SC) & $68 / 67$ & $1.01(1.00 ; 1.03)$ & 0.095 & $54 / 56$ \\
\hline XARcomp(lipPOP) (\% of SC) & $68 / 67$ & $0.99(0.97 ; 1.01)$ & 0.373 & $54 / 56$ \\
\hline \multicolumn{5}{|c|}{ AhR activity of dioxin and dioxin-like POPs } \\
\hline AhR-TEQ (pq/L)* & $52 / 45$ & $1.00(1.00 ; 1.00)$ & 0.553 & $52 / 45$ \\
\hline AhR-TEQ (pg/g lipid)* & $52 / 45$ & $1.00(1.00 ; 1.00)$ & 0.508 & $52 / 45$ \\
\hline \multicolumn{5}{|l|}{ XER activity of PFAA } \\
\hline EEQ(PFAA) (pM)* & $43 / 53$ & $1.06(0.95 ; 1.19)$ & 0.295 & $33 / 40$ \\
\hline XER(PFAA) $(\%$ of SC)* & $43 / 53$ & $1.01(0.99 ; 1.04)$ & 0.198 & $33 / 40$ \\
\hline XERcomp(PFAA) ( $\%$ of SC)* & $43 / 53$ & $1.01(0.98 ; 1.03)$ & 0.510 & $33 / 40$ \\
\hline
\end{tabular}

Adjusted analysis

OR $(95 \% \mathrm{Cl})$

$0.89(0.79: 1.00)$

$0.99(0.96 ; 1.02) \quad 0.364$

$0.99(0.96 ; 1.02) \quad 0.495$

$1.02(0.99 ; 1.04) \quad 0.198$

$1.00(0.97 ; 1.02) \quad 0.792$

$1.00(1.00 ; 1.00) \quad 0.553$

$1.00(1.00 ; 1.00) \quad 0.508$

$1.06(0.93 ; 1.20) \quad 0.408$

$1.02(0.99 ; 1.04) \quad 0.292$

$1.02(0.99 ; 1.05) \quad 0.214$

Adjusted analysis: age, parity, serum cotinine level, BMI, breastfeeding, and total serum lipid (only in lipPOP analyses) were considered as confounders using change in estimate. Significant and borderline significant $P$-values are given in bold.

*Analysis only including samples from 2011 to 2014

AhR-TEQ, AhR-mediated TCDD equivalent of the samples; $\mathrm{Cl}$, confidence interval; EEQ, estradiol equivalents; $n$, number of cases and controls included in the analyze; OR, odds ratio; XER and XAR, receptor activity of the serum extracts tested alone; XERcomp and XARcomp, competitive receptor activity of the serum extracts tested with co-treatment; $\%$ of SC, the serum samples $\%$ fold induction of the solvent control.

ratio has been highlighted, in addition to the effect of the hormones individually (Labrie 2006). The effect of androgens may be elicited directly through binding to the androgen receptor or indirectly through their potential to be aromatized into estrogens (Dimitrakakis \& Bondy 2009, Kotsopoulos \& Narod 2012). However, clinical in vivo data do not support that androgens alone increase breast cancer risk (Gadducci et al. 2005). Where the epidemiological focus has been on the effect of endogenous androgen hormone levels and postmenopausal treatment with androgens, the role of xenoandrogenic POPs and their association with breast cancer risk has been overlooked. A study investigating the in vitro xenoandrogenic effects of typical OCP mixtures in breast cancer cases and controls found that the typical breast cancer mixture displayed a higher degree of antiandrogenic effect (Rivero et al. 2015). We found that lipPOP serum mixtures decreasing the XAR activity reduced breast cancer risk significantly (Fig. 5). In the competitive analysis, upon co-exposure to a potent AR ligand, we did not see any effects on breast cancer risk, but the majority of lipPOP serum extracts $(77.9 \%$ for cases and $83.6 \%$ for controls) antagonized the AR activity (XARcomp). The mode of action for reduced risk with decreasing lipPOP xenoandrogenic activity is unclear. One mode of action could be by binding to the substratebinding site of aromatase and block the conversion of androgens to estrogens, thereby reducing breast cancer risk. A similar mode of action is seen for aromatase inhibitors used in treatment of breast cancer (Miller 2003) and several lipPOPs have been reported to interfere with aromatase activity (Sanderson et al. 2002, Woodhouse \& Cooke 2004, Kjeldsen et al. 2013). POPs seems to have the potential to disrupt the homeostasis and functions of androgens via their receptor activity. However, further studies on xenohormone activities in relation to breast cancer, and the possible mechanisms of xenoandrogenic POPs, are warranted.

In the 2011-2014 sample, AhR-TEQ was significantly lower in cases than controls and a reduced risk was observed with high AhR-TEQ levels. Similar results were seen for the 2000-2003 samples (Bonefeld-Jorgensen et al. 2011). Data from the two sampling periods were not pooled, since the AhR activity measurements were carried out in different laboratories using slightly different methods. The AhR has been shown to play a role in normal breast tissue development and in progression of breast cancer (Powell et al. 2013) and important crosstalk with the estrogen receptor exists (Hankinson 1995). In pregnant rats, a decreasing level in estrogen was observed upon exposure to TCDD (Chaffin et al. 1996), which may be explained by the induction of CYP1A1 and CYP1B1 (Hankinson 1995). Non-coplanar PCBs without dioxinlike activity have been shown to antagonize and inhibit the AhR pathway (Suh et al. 2003). Hence, the higher PCB levels in breast cancer cases compared to controls (Wielsøe et al. 2017) may explain the lower AhR-TEQ in cases.

We have previously reported significant associations between serum concentrations of single PFAAs and breast cancer risk, in the present study population (Wielsøe et al. 2017), our previous Greenlandic study 

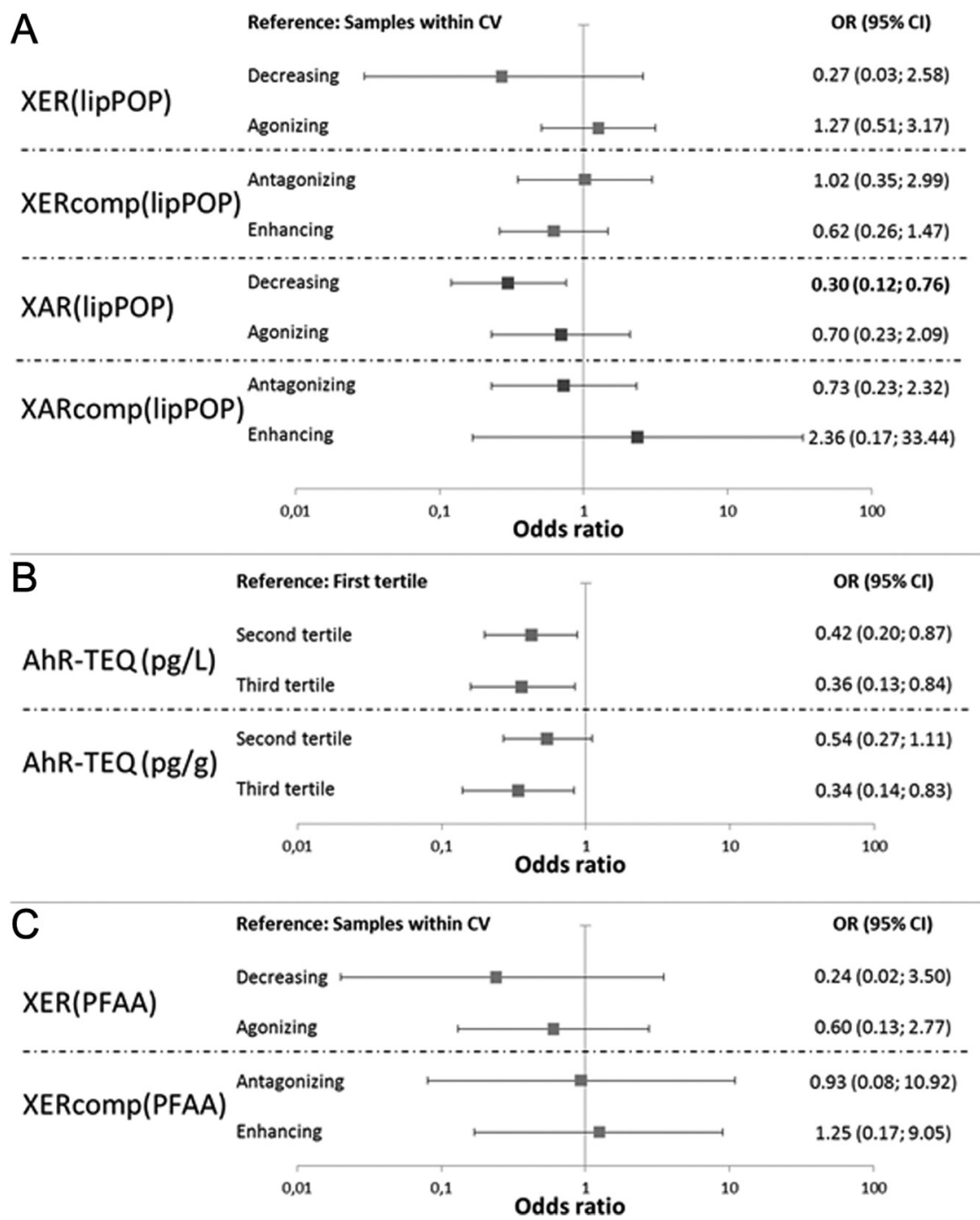

Figure 5

Odds ratio estimates from the categorical analyses of xenohormone activity and breast cancer risk. Forest plots of associations of xenohormone activity of serum extracted POP with breast cancer risk. Adjusted odds ratio estimates with $95 \%$ confidence interval (as horizontal lines). Age, parity, serum cotinine level, BMI, total serum lipid, and breastfeeding history were considered as confounders using the change in estimate principal. OR, odds ratio; $\mathrm{Cl}$, confidence interval; XER and XAR, receptor activity of the serum extracts tested alone; XERcomp and XARcomp, competitive receptor activity of the serum extracts tested with co-treatment by potent receptor ligand. For definition of decreasing/agonizing and antagonizing/enhancing samples, see 'Methods' section.
(Bonefeld-Jorgensen et al. 2011) and in a Danish prospective study (Bonefeld-Jorgensen et al. 2014b). However, no associations between the PFAA-induced ER activity (XER(PFAA), XERcomp(PFAA)) and breast cancer risk were seen in the present study (Fig. 5 and Table 4). The results could indicate that PFAAs affect breast cancer risk through other mechanisms than by their potential xenoestrogenic activity. PFAA exposure has been associated with other carcinogenic mechanisms in humans. The compounds may affect breast cancer risk through immune toxicity (Corsini et al. 2014), oxidative stress (Eriksen et al. 2010, Wielsoe et al. 2015), altered hormone levels (SHBG, TSH, T4, FSH and testosterone) (Tsai et al. 2015, 2017), altered epigenetic DNA methylation pattern (GuerreroPreston et al. 2010, Watkins et al. 2014) and altered gene expression (Fletcher et al. 2013, La Rocca et al. 2015).

The present study has some limitations. Firstly, the study included a relatively small sample size. Especially, the results on xenoestrogenic PFAA activity and dioxinlike activity, which only included data from the period 2010 to 2014. The narrow confidence intervals do, however, not indicate uncertain estimates. Secondly, due to the case-control design, our study might suffer from reverse causation bias as the serum samples were obtained from newly diagnosed breast cancer cases. Hormone and POP levels might have changed after disease onset, although we did limit the potential bias by only including patients before any treatment. Thirdly, we have previously reported that low concentrations of dehydroepiandrosterone sulfate (DHEAS) and estrone sulfate (E1S) are present in serum PFAA extracts and both hormones had estrogenic activity (Bjerregaard-Olesen et al. 2016). Low concentrations of DHEAS and E1S in PFAA serum extracts from young males and female did not affect the assessment of PFAA-induced estrogenic activity (Bjerregaard-Olesen et al. 2016), and the levels of DHEAS 
and E1S in older women and breast cancer cases are even lower than those reported for young males and females. Thus, we do not expect DHEAS and E1S to influence the results of the present study. Finally, we extracted the POP mixtures from serum samples. Samples from breast tissue would have been optimal, but collection of such samples is quite invasive and challenging, especially among the controls. Moreover, exposure to EDs may cause systemic alterations of the endocrine system, and not only affect the breast tissue. We believe that the serum POP-induced receptor activity is a good indicator for the long-term POP exposure, as serum levels of lipPOPs are highly correlated with the level in breast tissue (Rusiecki et al. 2005, ArtachoCordon et al. 2015).

An important strength of the present study is the measurement of the mixture effect of POP-related xenohormone and dioxin-like activity. Many studies have investigated the relation between POP exposure and breast cancer risk; however, most have investigated single compounds or related groups without considering possible synergetic, additive, or antagonistic mixture effects between the chemicals. By extracting the actual POP mixture from serum and determining the receptor activities, we account for possible mixture effects. However, our approach do not add information on the specific type of mixture effects occurring in the serum extracts. The exposure POP level in Greenlandic Inuit is very high and the exposure profile of the Inuit population differs from profiles seen in other parts of the world, e.g. Europe (Bonefeld-Jorgensen et al. 2006, Kruger et al. 2007). This emphasizes the importance of investigating the association with breast cancer in population with unique exposure profiles, such as the Greenlandic.

In summary, dioxin-like activities of serum lipPOP mixtures were significantly associated with breast cancer risk in Greenlandic Inuit women. The observation is consistent with the results from our previously Greenlandic breast cancer study (Bonefeld-Jorgensen et al. 2011) and calls for further investigation of the association in other populations. We found no consistent associations between POP-induced hormone receptor activities (ER and AR) and breast cancer risk. However, we did found a reduced risk for women with decreasing lipPOP xenoandrogenic (XAR(lipPOP)) activities. Our results indicate that lipPOPs might influence breast cancer risk through their endocrine-disrupting potential by influencing the homeostasis of hormone functions, but other mechanistic pathways may to be involved as well, especially for the PFAAs.

\section{Declaration of interest}

The authors declare that they have no conflicts of interest with regard to the research, authorship and publication of the research reported.

\section{Funding}

Financial support was gratefully received from The International Polar Year Committee (09-064624), The Commission for Scientific Research in Greenland (2015-111969), The Department for Health and Infrastructure (Greenland Self-government, Nuuk), Aarhus University and The Danish Environmental Agency (MST-112-00243).

\section{Acknowledgements}

The authors thank all the women participating in the study and gratefully acknowledge assistance from the staff at the clinical-chemistry hospital laboratory and other involved hospital staff at Dronning Ingrids Hospital in Nuuk, Greenland. A special thank you to head nurse Linda Seelk and medical doctor Ole Lind for their coordination support during the collection period. Furthermore, we wish to thank our colleagues at Centre for Arctic Health \& Molecular Epidemiology. They particularly want to thank Mandana Ghisari and Duy Anh Dang for support in the laboratory.

\section{References}

Anderson WF, Chatterjee N, Ershler WB \& Brawley OW 2002 Estrogen receptor breast cancer phenotypes in the Surveillance, Epidemiology, and End Results database. Breast Cancer Research and Treatment 76 27-36. (https://doi.org/10.1023/A:1020299707510)

Artacho-Cordon F, Fernandez-Rodriguez M, Garde C, Salamanca E, Iribarne-Duran LM, Torne P, Exposito J, Papay-Ramirez L, Fernandez MF, Olea N, et al. 2015 Serum and adipose tissue as matrices for assessment of exposure to persistent organic pollutants in breast cancer patients. Environmental Research 142 633-643. (https://doi.org/10.1016/j.envres.2015.08.020)

Bjerregaard-Olesen C, Bossi R, Bech BH \& Bonefeld-Jorgensen EC 2015 Extraction of perfluorinated alkyl acids from human serum for determination of the combined xenoestrogenic transactivity: a method development. Chemosphere 129 232-238. (https://doi. org/10.1016/j.chemosphere.2014.08.071)

Bjerregaard-Olesen C, Ghisari M, Kjeldsen LS, Wielsoe M \& BonefeldJorgensen EC 2016 Estrone sulfate and dehydroepiandrosterone sulfate: transactivation of the estrogen and androgen receptor. Steroids 105 50-58. (https://doi.org/10.1016/j.steroids.2015.11.009)

Bonefeld-Jorgensen EC, Andersen HR, Rasmussen TH \& Vinggaard AM 2001 Effect of highly bioaccumulated polychlorinated biphenyl congeners on estrogen and androgen receptor activity. Toxicology 158 141-153. (https://doi.org/10.1016/S0300-483X(00)00368-1)

Bonefeld-Jorgensen EC, Grunfeld HT \& Gjermandsen IM 2005 Effect of pesticides on estrogen receptor transactivation in vitro: a comparison of stable transfected MVLN and transient transfected MCF-7 cells. Molecular and Cellular Endocrinology 244 20-30. (https://doi. org/10.1016/j.mce.2005.01.017)

Bonefeld-Jorgensen EC, Hjelmborg PS, Reinert TS, Andersen BS, Lesovoy V, Lindh CH, Hagmar L, Giwercman A, Erlandsen M, Manicardi GC, et al. 2006 Xenoestrogenic activity in blood of European and Inuit populations. Environmental Health 5 12. (https:// doi.org/10.1186/1476-069X-5-12)

Bonefeld-Jorgensen EC, Long M, Bossi R, Ayotte P, Asmund G, Kruger T, Ghisari M, Mulvad G, Kern P, Nzulumiki P, et al. 2011 Perfluorinated compounds are related to breast cancer risk in Greenlandic Inuit:
(C) 2018 Society for Endocrinology Published by Bioscientifica Ltd. Printed in Great Britain 
a case control study. Environmental Health 10 88. (https://doi org/10.1186/1476-069X-10-88)

Bonefeld-Jorgensen EC, Ghisari M, Wielsoe M, Bjerregaard-Olesen C, Kjeldsen LS \& Long M 2014a Biomonitoring and hormonedisrupting effect biomarkers of persistent organic pollutants in vitro and ex vivo. Basic and Clinical Pharmacology and Toxicology 115 118-128. (https://doi.org/10.1111/bcpt.12263)

Bonefeld-Jorgensen EC, Long M, Fredslund SO, Bossi R \& Olsen J $2014 b$ Breast cancer risk after exposure to perfluorinated compounds in Danish women: a case-control study nested in the Danish National Birth Cohort. Cancer Causes and Control 25 1439-1448. (https://doi. org/10.1007/s10552-014-0446-7)

Brody JG, Moysich KB, Humblet O, Attfield KR, Beehler GP \& Rudel RA 2007 Environmental pollutants and breast cancer: epidemiologic studies. Cancer 109 2667-2711. (https://doi.org/10.1002/cncr.22655)

Chaffin CL, Peterson RE \& Hutz RJ 1996 In utero and lactational exposure of female Holtzman rats to 2,3,7,8-tetrachlorodibenzo-pdioxin: modulation of the estrogen signal. Biology of Reproduction $\mathbf{5 5}$ 62-67. (https://doi.org/10.1095/biolreprod55.1.62)

Corsini E, Luebke RW, Germolec DR \& DeWitt JC 2014 Perfluorinated compounds: emerging POPs with potential immunotoxicity. Toxicology Letters 230 263-270. (https://doi.org/10.1016/j. toxlet.2014.01.038)

Cote S, Ayotte P, Dodin S, Blanchet C, Mulvad G, Petersen HS, Gingras S \& Dewailly E 2006 Plasma organochlorine concentrations and bone ultrasound measurements: a cross-sectional study in peri-and postmenopausal Inuit women from Greenland. Environmental Health 5 33. (https://doi.org/10.1186/1476-069X-5-33)

Dai X, Xiang L, Li T \& Bai Z 2016 Cancer hallmarks, biomarkers and breast cancer molecular subtypes. Journal of Cancer 7 1281-1294. (https://doi.org/10.7150/jca.13141)

Deutch B, Pedersen HS, Asmund G \& Hansen JC 2007 Contaminants, diet, plasma fatty acids and smoking in Greenland 1999-2005. Science of the Total Environment 372 486-496. (https://doi. org/10.1016/j.scitotenv.2006.10.043)

Dimitrakakis C \& Bondy C 2009 Androgens and the breast. Breast Cancer Research 11 212. (https://doi.org/10.1186/bcr2413)

Eriksen KT, Raaschou-Nielsen O, Sorensen M, Roursgaard M, Loft S \& Moller P 2010 Genotoxic potential of the perfluorinated chemicals PFOA, PFOS, PFBS, PFNA and PFHxA in human HepG2 cells. Mutation Research 700 39-43. (https://doi.org/10.1016/j. mrgentox.2010.04.024)

Evans RM, Scholze M \& Kortenkamp A 2012 Additive mixture effects of estrogenic chemicals in human cell-based assays can be influenced by inclusion of chemicals with differing effect profiles. PLOS ONE 7 e43606. (https://doi.org/10.1371/journal.pone.0043606)

Ferlay J, Soerjomataram I, Dikshit R, Eser S, Mathers C, Rebelo M, Parkin DM, Forman D \& Bray F 2015 Cancer incidence and mortality worldwide: sources, methods and major patterns in GLOBOCAN 2012. International Journal of Cancer 136 E359-E386. (https://doi.org/10.1002/ijc.29210)

Fletcher T, Galloway TS, Melzer D, Holcroft P, Cipelli R, Pilling LC, Mondal D, Luster M \& Harries LW 2013 Associations between PFOA, PFOS and changes in the expression of genes involved in cholesterol metabolism in humans. Environment International 57-58 2-10. (https://doi.org/10.1016/j.envint.2013.03.008)

Gadducci A, Gargini A, Palla E, Fanucchi A \& Genazzani AR 2005 Polycystic ovary syndrome and gynecological cancers: is there a link? Gynecological Endocrinology 20 200-208. (https://doi. org/10.1080/09513590400021201)

Guerrero-Preston R, Goldman LR, Brebi-Mieville P, Ili-Gangas C, LeBron C, Hernandez-Arroyo M, Witter FR, Apelberg BJ, Roystacher M, Jaffe A, et al. 2010 Global DNA hypomethylation is associated with in utero exposure to cotinine and perfluorinated alkyl compounds. Epigenetics 5 539-546. (https://doi.org/10.4161/ epi.5.6.12378)
Hankinson O 1995 The aryl hydrocarbon receptor complex. Annual Review of Pharmacology and Toxicology 35 307-340. (https://doi. org/10.1146/annurev.pa.35.040195.001515)

Henderson BE \& Feigelson HS 2000 Hormonal carcinogenesis. Carcinogenesis 21 427-433. (https://doi.org/10.1093/carcin/21.3.427)

Hjelmborg PS, Ghisari M \& Bonefeld-Jorgensen EC 2006 SPE-HPLC purification of endocrine-disrupting compounds from human serum for assessment of xenoestrogenic activity. Analytical and Bioanalytical Chemistry 385 875-887. (https://doi.org/10.1007/s00216-006-0463-9)

Ibarluzea JM, Fernandez MF, Santa-Marina L, Olea-Serrano MF, Rivas AM, Aurrekoetxea JJ, Exposito J, Lorenzo M, Torne P, Villalobos M, et al. 2004 Breast cancer risk and the combined effect of environmental estrogens. Cancer Causes and Control 15 591-600.

Key T, Appleby P, Barnes I, Reeves G, Endogenous H \& Breast Cancer Collaborative Group 2002 Endogenous sex hormones and breast cancer in postmenopausal women: reanalysis of nine prospective studies. Journal of the National Cancer Institute 94 606-616. (https:// doi.org/10.1093/jnci/94.8.606)

Kjeldsen LS, Ghisari M \& Bonefeld-Jorgensen EC 2013 Currently used pesticides and their mixtures affect the function of sex hormone receptors and aromatase enzyme activity. Toxicology and Applied Pharmacology 272 453-464. (https://doi.org/10.1016/j.taap.2013.06.028)

Kortenkamp A 2007 Ten years of mixing cocktails: a review of combination effects of endocrine-disrupting chemicals. Environmental Health Perspectives 115 (Supplement 1) 98-105. (https://doi. org/10.1289/ehp.9357)

Kotsopoulos J \& Narod SA 2012 Androgens and breast cancer. Steroids 77 1-9. (https://doi.org/10.1016/j.steroids.2011.10.002)

Kruger T, Hjelmborg PS, Jonsson BA, Hagmar L, Giwercman A, Manicardi GC, Bizzaro D, Spano M, Rignell-Hydbom A, Pedersen HS, et al. 2007 Xenoandrogenic activity in serum differs across European and Inuit populations. Environmental Health Perspectives 115 (Supplement 1) 21-27. (https://doi.org/10.1289/ehp.9353)

Kruger T, Long M, Ghisari M \& Bonefeld-Jorgensen EC 2012 The combined effect of persistent organic pollutants in the serum POP mixture in Greenlandic Inuit: xenoestrogenic, xenoandrogenic and dioxin-like transactivities. Biomarkers 17 692-705. (https://doi.org/10 .3109/1354750X.2012.700950)

La Rocca C, Tait S, Guerranti C, Busani L, Ciardo F, Bergamasco B, Perra G, Mancini FR, Marci R, Bordi G, et al. 2015 Exposure to endocrine disruptors and nuclear receptors gene expression in infertile and fertile men from italian areas with different environmental features. International Journal of Environmental Research and Public Health 12 12426-12445. (https://doi.org/10.3390/ijerph121012426)

Labrie F 2006 Dehydroepiandrosterone, androgens and the mammary gland. Gynecological Endocrinology 22 118-130. (https://doi. org/10.1080/09513590600624440)

Lakis S, Kotoula V, Eleftheraki AG, Batistatou A, Bobos M, Koletsa T, Timotheadou E, Chrisafi S, Pentheroudakis G, Koutras A, et al. 2014 The androgen receptor as a surrogate marker for molecular apocrine breast cancer subtyping. Breast 23 234-243. (https://doi. org/10.1016/j.breast.2014.02.013)

Leng L, Li J, Luo XM, Kim JY, Li YM, Guo XM, Chen X, Yang QY, Li G \& Tang NJ 2016 Polychlorinated biphenyls and breast cancer: a congener-specific meta-analysis. Environment International $\mathbf{8 8}$ 133-141. (https://doi.org/10.1016/j.envint.2015.12.022)

Long M, Andersen BS, Lindh CH, Hagmar L, Giwercman A, Manicardi GC, Bizzaro D, Spano M, Toft G, Pedersen HS, et al. 2006 Dioxin-like activities in serum across European and Inuit populations. Environmental Health 5 14. (https://doi. org/10.1186/1476-069X-5-14)

Miller WR 2003 Aromatase inhibitors: mechanism of action and role in the treatment of breast cancer. Seminars in Oncology 30 3-11. (https://doi.org/10.1016/S0093-7754(03)00302-6)

Morck TA, Erdmann SE, Long M, Mathiesen L, Nielsen F, Siersma VD, Bonefeld-Jorgensen EC \& Knudsen LE 2014 PCB concentrations and 
dioxin-like activity in blood samples from Danish school children and their mothers living in urban and rural areas. Basic and Clinical Pharmacology and Toxicology 115 134-144. (https://doi.org/10.1111/ bcpt.12214)

Ogawa Y, Hai E, Matsumoto K, Ikeda K, Tokunaga S, Nagahara H, Sakurai K, Inoue T \& Nishiguchi Y 2008 Androgen receptor expression in breast cancer: relationship with clinicopathological factors and biomarkers. International Journal of Clinical Oncology $\mathbf{1 3}$ 431-435. (https://doi.org/10.1007/s10147-008-0770-6)

Pastor-Barriuso R, Fernandez MF, Castano-Vinyals G, Whelan D, PerezGomez B, Llorca J, Villanueva CM, Guevara M, Molina-Molina JM, Artacho-Cordon F, et al. 2016 Total effective xenoestrogen burden in serum samples and risk for breast cancer in a population-based multicase-control study in Spain. Environmental Health Perspectives 124 1575-1582. (https://doi.org/10.1289/EHP157)

Powell JB, Goode GD \& Eltom SE 2013 The aryl hydrocarbon receptor: a target for breast cancer therapy. Journal of Cancer Therapy $\mathbf{4}$ 1177-1186. (https://doi.org/10.4236/jct.2013.47137)

Rajapakse N, Silva E \& Kortenkamp A 2002 Combining xenoestrogens at levels below individual no-observed-effect concentrations dramatically enhances steroid hormone action. Environmental Health Perspectives 110 917-921. (https://doi.org/10.1289/ehp.02110917)

Rivero J, Luzardo OP, Henriquez-Hernandez LA, Machin RP, Pestano J, Zumbado M, Boada LD, Camacho M \& Valeron PF 2015 In vitro evaluation of oestrogenic/androgenic activity of the serum organochlorine pesticide mixtures previously described in a breast cancer case control study. Science of the Total Environment $\mathbf{5 3 7}$ 197-202. (https://doi.org/10.1016/j.scitotenv.2015.08.016)

Rusiecki JA, Matthews A, Sturgeon S, Sinha R, Pellizzari E, Zheng T \& Baris D 2005 A correlation study of organochlorine levels in serum, breast adipose tissue, and gluteal adipose tissue among breast cancer cases in India. Cancer Epidemiology, Biomarkers and Prevention 14 1113-1124. (https://doi.org/10.1158/1055-9965.EPI-04-0356)

Russo J \& Russo IH 2006 The role of estrogen in the initiation of breast cancer. Journal of Steroid Biochemistry and Molecular Biology 102 89-96. (https://doi.org/10.1016/j.jsbmb.2006.09.004)

Sanderson JT, Boerma J, Lansbergen GWA \& van den Berg M 2002 Induction and inhibition of aromatase (CYP19) activity by various classes of pesticides in H295R human adrenocortical carcinoma cells. Toxicology and Applied Pharmacology 182 44-54. (https://doi. org/10.1006/taap.2002.9420)
Scholze M, Silva E \& Kortenkamp A 2014 Extending the applicability of the dose addition model to the assessment of chemical mixtures of partial agonists by using a novel toxic unit extrapolation method. PLOS ONE 9 e88808. (https://doi.org/10.1371/journal.pone.0088808)

Suh J, Kang JS, Yang KH \& Kaminski NE 2003 Antagonism of aryl hydrocarbon receptor-dependent induction of CYP1A1 and inhibition of IgM expression by di-ortho-substituted polychlorinated biphenyls. Toxicology and Applied Pharmacology 187 11-21. (https:// doi.org/10.1016/S0041-008X(02)00040-6)

Tsai MS, Lin CY, Lin CC, Chen MH, Hsu SHJ, Chien KL, Sung FC, Chen PC \& Su TC 2015 Association between perfluoroalkyl substances and reproductive hormones in adolescents and young adults. International Journal of Hygiene and Environmental Health 218 437-443. (https://doi.org/10.1016/j.ijheh.2015.03.008)

Tsai MS, Lin CC, Chen MH, Hsieh WS \& Chen PC 2017 Perfluoroalkyl substances and thyroid hormones in cord blood. Environmental Pollution 222 543-548. (https://doi.org/10.1016/j. envpol.2016.11.027)

Watkins DJ, Wellenius GA, Butler RA, Bartell SM, Fletcher T \& Kelsey KT 2014 Associations between serum perfluoroalkyl acids and LINE-1 DNA methylation. Environment International 63 71-76. (https://doi. org/10.1016/j.envint.2013.10.018)

Wielsoe M, Long M, Ghisari M \& Bonefeld-Jorgensen EC 2015 Perfluoroalkylated substances (PFAS) affect oxidative stress biomarkers in vitro. Chemosphere 129 239-245. (https://doi. org/10.1016/j.chemosphere.2014.10.014)

Wielsøe M, Gudmundsdottir S \& Bonefeld-Jorgensen EC 2016 Reproductive history and dietary habits and breast cancer risk in Greenlandic Inuit: a case control study. Public Health 137 50-58. (https://doi.org/10.1016/j.puhe.2016.06.016)

Wielsøe M, Kern P \& Bonefeld-Jørgensen EC 2017 Serum levels of environmental pollutants is a risk factor for breast cancer in Inuit: a case control study. Environmental Health 16 56. (https://doi. org/10.1186/s12940-017-0269-6)

Woodhouse AJ \& Cooke GM 2004 Suppression of aromatase activity in vitro by PCBs 28 and 105 and Aroclor 1221. Toxicology Letters 152 91-100. (https://doi.org/10.1016/j.toxlet.2004.04.009)

Zhang J, Huang Y, Wang X, Lin K \& Wu K 2015 Environmental polychlorinated biphenyl exposure and breast cancer risk: a metaanalysis of observational studies. PLOS ONE 10 e0142513. (https:// doi.org/10.1371/journal.pone.0142513)

Received in final form 5 December 2017

Accepted 13 December 2017

Accepted Preprint published online 13 December 2017
() 2018 Society for Endocrinology Published by Bioscientifica Ltd. Printed in Great Britain 